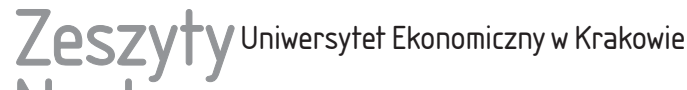 Naukowe}

Zarządzanie
922

ISSN 1898-6447

Zesz. Nauk. UEK, 2013; 922: 27-45

Jolanta Walas-Trębacz

Katedra Procesu Zarządzania

Uniwersytet Ekonomiczny w Krakowie

\title{
Metodyka analizy łańcucha wartości przedsiębiorstwa
}

\section{Streszczenie}

Celem niniejszego artykułu jest przedstawienie jednego ze sposobów zwiększania wartości przedsiębiorstwa poprzez identyfikację i ocenę struktury jego łańcucha wartości. W artykule wskazano przesłanki, które przyczyniają się do konieczności zwiększenia zainteresowania badaniem łańcucha wartości przedsiębiorstwa.

Główną częścią opracowania jest zaprezentowanie metodyki analizy łańcucha wartości poprzez charakterystykę jej poszczególnych etapów, a mianowicie: identyfikacji potrzeb i oczekiwań klientów przedsiębiorstwa, analizy procesów tworzących łańcuch wartości przedsiębiorstwa, analizy kosztów procesów w istniejącej konfiguracji łańcucha wartości, oceny zasobów i kompetencji w łańcuchu wartości przedsiębiorstwa oraz badaniu relacji przedsiębiorstwa w łańcuchu wartości.

Ważnym aspektem $\mathrm{w}$ analizie łańcucha wartości jest ustalenie zestawu kryteriów, które pozwolą na ocenę funkcjonowania istniejącego modelu biznesu z punktu widzenia procesu zaspokajania potrzeb klienta oraz procesu tworzenia wartości z pozycji kosztów i efektywności podejmowanych działań.

Słowa kluczowe: łańcuch wartości, model łańcucha wartości, metodyka analizy łańcucha wartości, analiza procesowa przedsiębiorstwa.

\section{Wprowadzenie}

Współczesne organizacje gospodarcze działające w niepewnym, dynamicznie zmieniającym się otoczeniu za główny cel działalności stawiają wzrost jej wartości. Podejmując decyzje strategiczne dotyczące przyjęcia określonej 
koncepcji budowy wartości i jej wdrażania, przedsiębiorstwo może dokonać wyboru sposobu zwiększenia tej wartości w wyniku: wzrostu efektywności finansowej, poprawy produktywności, doskonalenia struktury łańcucha wartości i rozwijania sieci organizacyjnych, wykorzystania potencjału pracy i jego produktywności oraz tworzenia wartości z perspektywy klienta.

Celem niniejszego artykułu jest przedstawienie jednego ze sposobów zwiększania wartości przedsiębiorstwa poprzez wykorzystanie analizy i oceny struktury jego łańcucha wartości. W artykule wskazano przesłanki, które powodują konieczność zwiększenia zainteresowania badaniem łańcucha wartości przedsiębiorstwa.

Zaprezentowano metodykę analizy łańcucha wartości poprzez charakterystykę jej poszczególnych etapów, takich jak: identyfikacja potrzeb i oczekiwań klientów przedsiębiorstwa, analiza procesów tworzących łańcuch wartości przedsiębiorstwa, analiza kosztów procesów w istniejącej konfiguracji łańcucha wartości, ocena zasobów i kompetencji w łańcuchu wartości przedsiębiorstwa oraz badanie relacji (zewnętrznych i wewnętrznych) przedsiębiorstwa w łańcuchu wartości.

Proponowana metodyka badania łańcucha wartości pozwoli kierownictwu zrozumieć potrzebę celowości jej wykorzystania w procesie zarządzania strategicznego przedsiębiorstwa, co niewątpliwie wiąże się z zarządzaniem kosztami, procesami, przychodami i relacjami oraz podejmowaniem decyzji związanej z wyborem efektywnego modelu biznesu. Ważnym aspektem w analizie łańcucha wartości jest ustalenie zestawu kryteriów, które pozwolą na ocenę funkcjonowania istniejącego modelu biznesu ze względu na proces zaspokajania potrzeb klienta oraz proces tworzenia wartości z pozycji kosztów i efektywności podejmowanych działań.

\section{2. Łańcuch wartości jako przedmiot badania}

Łańcuch wartości (value chain) jest uporządkowanym ciągiem różnego rodzaju funkcji (działań) generujących wartość produktu, która jest określona przez relacje rynkowe między firmą a nabywcą. Jest to ciąg powiązanych ze sobą (szeregowo lub równolegle) faz procesu zarządzania i procesów wykonawczych, odniesionych do określonego sektora działalności firmy. To sekwencja funkcji danego systemu, np. przedsiębiorstwa lub szerszego układu kooperacyjnego, mającego rozwinięte relacje zewnętrzne [Stabryła 2007, s. 165]. Koncepcja łańcucha wartości, nazywanego również łańcuchem ekonomicznym [Drucker 1976, s. 120], jest ściśle związana z wartością dodaną powstającą w kolejnych ogniwach procesów gospodarczych. Charakteryzuje ona przyrost wartości produktów, a zarazem kształtowanie się kosztów w przedsiębiorstwie ${ }^{1}$. Jednym z charakterystycznych terminów

${ }^{1}$ Z łańcuchem wartości niektórzy autorzy wiążą pojęcie łańcucha dostaw oznaczającego sieć organizacji zaangażowanych poprzez powiązanie z dostawcami i odbiorcami, w różne procesy 
tej koncepcji jest wartość, która odnosi się do poszczególnych ogniw łańcucha i wyraża bądź wynik końcowy, czyli zysk, bądź efekty pośrednie, ale może odnosić się do kosztów, jakie są generowane we wszystkich stadiach określonego procesu [Stabryła 2007, s. 165-166].

Model łańcucha wartości przedstawił w 1985 r. M.E. Porter ${ }^{2}$. Ujął go w formę schematu, na którym została nakreślona w sposób bardzo ogólny struktura powiązanych ze sobą funkcji głównych i pomocniczych, jakie występują w przedsiębiorstwie. Łańcuch wartości według M.E. Portera to narzędzie rozpoznawania sposobów tworzenia większej wartości dla klienta z pozycji przedsiębiorstwa, którego celem jest maksymalizacja wartości dodanej (zysku) [Porter 1985, s. 35]. Wartość dodana może dotyczyć podaży i wówczas jest kojarzona z przedsiębiorstwem, jak i popytu, wówczas odnosi się do klienta akceptującego cenę i inne korzyści związane z produktem/usługą.

Łańcuch wartości poprzez sekwencję działań (podstawowych i pomocniczych) w nim zachodzących bierze udział w generowaniu zysku. Lecz nie każde działanie ma istotny wpływ na przewagę konkurencyjną i efektywność funkcjonowania przedsiębiorstwa. Wybór działań, które będą w przedsiębiorstwie realizowane oraz wskazanie tych podlegających doskonaleniu ma więc podstawowe znaczenie dla przedsiębiorstwa.

Złożoność problematyki oraz niedostatecznie rozwinięta metodologia projektowania łańcucha wartości sprawiają, że podejmowany w praktyce kierunek poszukiwania wartości dodanej przedsiębiorstwa odbywa się na podstawie metody analizy ekonomicznej lub finansowej. Interesującą perspektywę badawczą w podnoszeniu wartości dodanej przedsiębiorstwa stanowi także analiza zmian modelu łańcucha wartości³.

Analiza modelu łańcucha wartości to sposób na poszukiwanie źródeł sprawności i niesprawności przedsiębiorstwa, a przede wszystkim obszarów działań, w których przedsiębiorstwo dysponuje szczególnymi kompetencjami wytwórczymi, technologicznymi, organizacyjnymi, informacyjnymi, kooperacyjnymi,

i działania, które tworzą wartość w postaci produktów i usług dostarczanych ostatecznym konsumentom [Christopher 2000, s. 14].

${ }^{2}$ Bazowy łańcuch wartości stanowi propozycję modelu przedsiębiorstwa jako systemu, obrazującego całkowitą jego wartość. M.E. Porter definiuje wartość jako „sumę pieniężną, którą nabywcy są skłonni zapłacić za to, czego firma dostarcza" [Porter 1985, s. 35].

${ }^{3}$ Nowatorstwo metody przedstawionej przez M.E. Portera przejawiało się nie tyle w znanym od wielu lat podejściu systemowym, ale w obranym przez niego podstawowym elemencie systemu przedsiębiorstwa - działaniu w miejsce funkcji oraz zamianie perspektywy producenta na perspektywę klienta. Współczesna terminologia nazywa te cechy podejściem procesowym oraz orientacją na klienta [Czakon 2003, s. 31]. 
mogącymi stać się źródłem przewagi konkurencyjnej ${ }^{4}$ Zatem czynności podstawowe występujące w łańcuchu wartości mają strategiczne znaczenie dla przedsiębiorstwa, ponieważ w wyniku ich realizacji powstaje wartość dodana.

Obecnie następuje radykalne odwrócenie tradycyjnego łańcucha wartości (rozpoczynającego się od funkcji przedprodukcyjnych) na rzecz współczesnego łańcucha, w którym klient staje się pierwszym ogniwem oraz czynnikiem sprawczym określającym całą resztę działań podejmowanych w firmie [Webb i Glie 2001, s. 14].

Każde przedsiębiorstwo ma indywidualny łańcuch procesów przyczyniających się do tworzenia wartości dla klientów. Istnieje jednak możliwość stworzenia ogólnego modelu łańcucha tworzenia wartości, który przedsiębiorstwa mogą adaptować do własnych potrzeb, odpowiednio programując przyszłe procesy wewnętrzne [Kaplan i Norton 2002, s. 99]. Rys. 1 przedstawia trzy grupy podstawowych procesów w łańcuchu wartości.

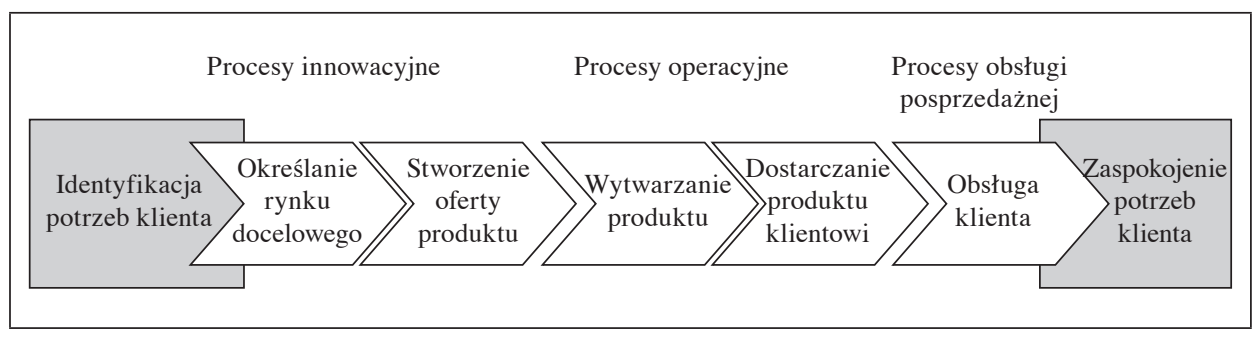

Rys. 1. Perspektywa procesów wewnętrznych - ogólny model łańcucha wartości Źródło: [Kaplan i Norton 2002, s. 99].

Analiza łańcucha wartości, aby mogła przynieść kadrze kierowniczej określone korzyści, winna być realizowana według dobrze przemyślanej i opracowanej metodyki, w której głównym przedmiotem badań są przede wszystkim:

- potrzeby klientów (obecnych i potencjalnych),

- procesy (podstawowe i pomocnicze) wpływające na tworzenie wartości dodanej,

- ponoszone koszty na utrzymanie i sprawną realizację procesów oraz ich ocena,

- zasoby i kompetencje przedsiębiorstwa wykorzystywane w tworzeniu wartości dodanej,

- relacje utrzymywane wewnątrz i na zewnątrz przedsiębiorstwa.

4 Analiza łańcucha wartości jest to analiza ponoszonych kosztów i uzyskiwanych efektów w odniesieniu do każdej czynności (działań) kreującej wartość, a także stanowi sposób poszukiwania możliwości usprawniania tych czynności [Matwiejczuk 2010, s. 17]. 
Takie podejście wymaga konieczności zaprojektowania i wdrożenia w przedsiębiorstwie systemu zarządzania, który umożliwiłby uporządkowanie wszystkich działań w firmie tak, aby uzyskać efekt synergii w postaci spełniania zakładanych poziomów wartości dodanej wobec interesariuszy oraz możliwość ich reorganizacji na następne okresy.

\section{Dobór kryteriów oceny lańcucha wartości przedsiębiorstwa}

Doskonalenie łańcucha wartości, aby przynosiło właściwe rezultaty w przedsiębiorstwie, powinno być poprzedzone przeprowadzeniem analizy istniejącego łańcucha wartości z wykorzystaniem zestawu opracowanych wcześniej kryteriów jego oceny. Ocena łańcucha wartości może być przeprowadzana z zastosowaniem miar syntetycznych i cząstkowych. Poniżej przedstawiono przykładowe syntetyczne kryteria oceny łańcucha wartości, a mianowicie:

- skuteczność realizacji celów w łańcuchu wartości przedsiębiorstwa,

- funkcjonalność łańcucha wartości przedsiębiorstwa,

- efektywność zarządzania łańcuchem wartości przedsiębiorstwa,

- koszty wynikające z łańcucha wartości przedsiębiorstwa,

- wartość dodana z łańcucha wartości,

- czas realizacji wartości dla klienta,

- elastyczność łańcucha wartości przedsiębiorstwa,

- jakość łańcucha wartości przedsiębiorstwa,

- struktura (architektura) łańcucha wartości przedsiębiorstwa

- koordynacja i integracja łańcucha wartości,

- poziom relacji (powiązań) w łańcuchu wartości,

- ryzyko w istniejącym łańcuchu wartości,

- zakres outsourcingu i insourcingu w łańcuchu wartości,

- zakres stosowanych metod w kształtowaniu łańcucha wartości,

- zakres i skuteczność monitoringu łańcucha wartości przedsiębiorstwa.

Sposób i zakres wykorzystania wymienionych kryteriów w ocenie łańcucha wartości będzie zależał od stopnia wykorzystania wyników i możliwości uzyskania danych do przeprowadzenia tej oceny.

Kryteria oceny łańcucha wartości można także określać i rozbudowywać $\mathrm{w}$ innych wymiarach, $\mathrm{np}$. biorąc pod uwagę ocenę poszczególnych procesów podstawowych: logistyki, projektowania, produkcji, świadczenia usług, sprzedaży, obsługi klienta oraz procesów pomocniczych, takich jak: finanse, marketing, technologia, zasoby ludzkie, infrastruktura. 


\section{Analiza istniejącego łańcucha wartości przedsiębiorstwa}

Na metodykę analizy łańcucha wartości przedsiębiorstwa składa się pięć następujących etapów:

1) identyfikacja potrzeb i oczekiwań klientów (obecnych i potencjalnych) przedsiębiorstwa,

2) analiza procesów wpływających na tworzenie wartości dodanej,

3) analiza kosztów w istniejącej konfiguracji łańcucha wartości,

4) ocena zasobów i kompetencji w łańcuchu wartości przedsiębiorstwa,

5) ocena relacji utrzymywanych wewnątrz i na zewnątrz łańcucha wartości przedsiębiorstwa.

\section{Etap 1. Identyfikacja potrzeb i oczekiwań klientów przedsiębiorstwa}

Współczesna walka konkurencyjna na rynku to walka o klienta. Podstawą wszystkich decyzji przedsiębiorstw o wyborze profilu produkcji, metodach gospodarowania i wytwarzania, sprzedaży, komunikacji z rynkiem, a także prowadzenia badań rynkowych są nie tylko wewnętrzne uwarunkowania technologiczne i organizacyjne przedsiębiorstwa, a stają się przede wszystkim oczekiwania i preferencje nabywców, które przekładają się na wpływy i zyski przedsiębiorstwa.

Kluczowym pojęciem w teorii zarządzania staje się kategoria wartości, ponieważ przetrwanie i długoterminowy sukces przedsiębiorstw na rynku jest determinowany stałym tworzeniem i dostarczaniem klientom właściwej (oczekiwanej) wartości. Jednocześnie kategoria ta jest niejednoznaczna, gdyż może być interpretowana w wielu różnych wymiarach (ekonomicznym, marketingowym, socjologicznym, psychologicznym, technicznym, aksjologicznym), a jej postrzeganie zależy głównie od osoby odbiorcy i jego oczekiwań.

Kompleksowej oceny istoty wartości z punktu widzenia klienta dokonał $\mathrm{Ph}$. Kotler. Według niego wartość dla klienta jest „oferowaną sumą użyteczności, czyli dokonaną przez niego oceną ogólnej zdolności produktu/usługi do zaspokojenia potrzeb" [Kotler 2005, s. 7, s. 33]. Stanowi ona różnicę między sumą korzyści, jakich oczekuje on od danego produktu/usługi, a kosztami związanymi z jego nabyciem. Korzyści dla klienta znajdują wyraz w oczekiwanych przez niego atrybutach, jakie musi posiadać produkt/usługa oraz ogólnym wizerunkiem przedsiębiorstwa, natomiast koszty stanowią: wydatki strice finansowe oraz koszty zużytego czasu, energii czy też koszty psychiczne. Klient ustala rzeczywistą wartość produktu/usługi, porównując ją z wartością ofert konkurencyjnych i podejmuje ostateczną decyzję o nabyciu konkretnego produktu/usługi ${ }^{5}$.

5 Wartość dla klienta jest kategorią: subiektywną, dynamiczną, postrzeganą i bezpośrednio niemierzalną [Szymura-Tyc 2004, s. 197]. Pojęcie wartości dla klienta oraz pojęcia pokrewne zostały szerzej wyjaśnione w opracowaniu [Beliczyński 2011, s. 56-63]. 
Ekonomiczny wymiar wartości - wartość dodana dla przedsiębiorstwa - wyraża wysokość zrealizowanego obrotu uzyskanego w efekcie zaangażowania różnego rodzaju nakładów i wykonania procesu transformacji. Istotnym wymiarem wartości dla przedsiębiorstwa jest zatem uzyskana nadwyżka korzyści w porównaniu z konkurentami w wyniku dostarczenia wyższej wartości dla klienta, gdyż to określa jego większy potencjał rozwoju. Pozycja firmy względem jej konkurentów opiera się na wartości. Jest ona korzystna, gdy tworzona wartość jest większa niż koszty związane z jej uzyskaniem [Kafel 2002, s. 42]. Tworzenie maksymalnej wartości dodanej dla przedsiębiorstwa (przy wysokiej relacji wartości do ceny i przy niskim poziomie kosztów) może być osiągnięte poprzez: doskonałość operacyjną (operational excellence), dostosowanie produktu do potrzeb indywidualnego klienta (customer intimacy) oraz przywództwo produktowe (product leadership) [Koźmiński 2004, s. 63-65].

Stan początkowy procesu tworzenia wartości determinowany jest odpowiednim ukierunkowaniem całego systemu (sieci wartości, przedsiębiorstwa) na spełnienie rozpoznanych wymagań i zrealizowanie w wyniku całościowego procesu transformacji pożądanych przez klientów wartości. Przebiegowi procesu tworzenia wartości musi towarzyszyć ciągła współpraca między podmiotami będącymi uczestnikami systemu w takich kluczowych procesach, jak: projektowanie i doskonalenie produktu, właściwe dostarczanie i obsługa klienta. Rys. 2 przedstawia miejsce klienta w systemie tworzenia wartości.

Wiedza o potrzebach klienta jest przekładana nie tylko na poszukiwanie wyjątkowej oferty produktu przynoszącej klientowi wartość dodaną, ale wykorzystywana bywa do podejmowania decyzji o zmianie modelu działalności firmy. Znajomość potrzeb klientów umożliwia segmentację klientów celem prowadzenia stałych pogłębionych analiz [Rutkowski 2000, s. 26-27].

W analizie omawianego problemu bardzo ważne miejsce zajmują narzędzia tworzące stale rozbudowującą się „ekonomikę klienta”, której elementami są między innymi: cena, koszt użytkowania wyrobu, przechowywanie i pozbycie się produktu, a także czas zużywany na transakcję zakupu, a nawet dyskomfort jego użytkowania.

Przykładem wykorzystania wiedzy opartej na „ekonomice klienta” może być oferta Microsoftu zapewniająca nabywcom standardy, łatwość stosowania i koszyk programów użytkowych [Slywotzky, Morrison i Andelman 2000, s. 43]. Nowe podejście w analizie, w wyniku selekcjonowania i podziału klientów na grupy,

${ }^{6}$ W „ekonomice klienta” chodzi o zwrócenie uwagi na posługiwanie się określonym zestawem parametrów, który jest coraz bardziej przez niego rozbudowywany, aby dokonać wyboru wartościowego z jego punktu widzenia produktu/usługi. Istotną rolę podczas zakupu odgrywa nie tylko ocena samego produktu, ale także dodatkowe wartości, jakie może uzyskać klient, np.: niskie koszy eksploatacji, czy możliwość recyklingu produktu. 
cechuje się podejmowaniem prób prognozowania potrzeb i priorytetów. Równocześnie przedsiębiorstwo usiłuje wpływać na potrzeby klientów, kierując się chęcią maksymalizacji wartości firmy. Dodatkowa korzyść dla firmy jest często osiągana w wyniku tzw. przechwytywania wartości, które coraz częściej odbywa się poprzez sprzedaż dodatkowych usług [Rokita 2005, s. 188].

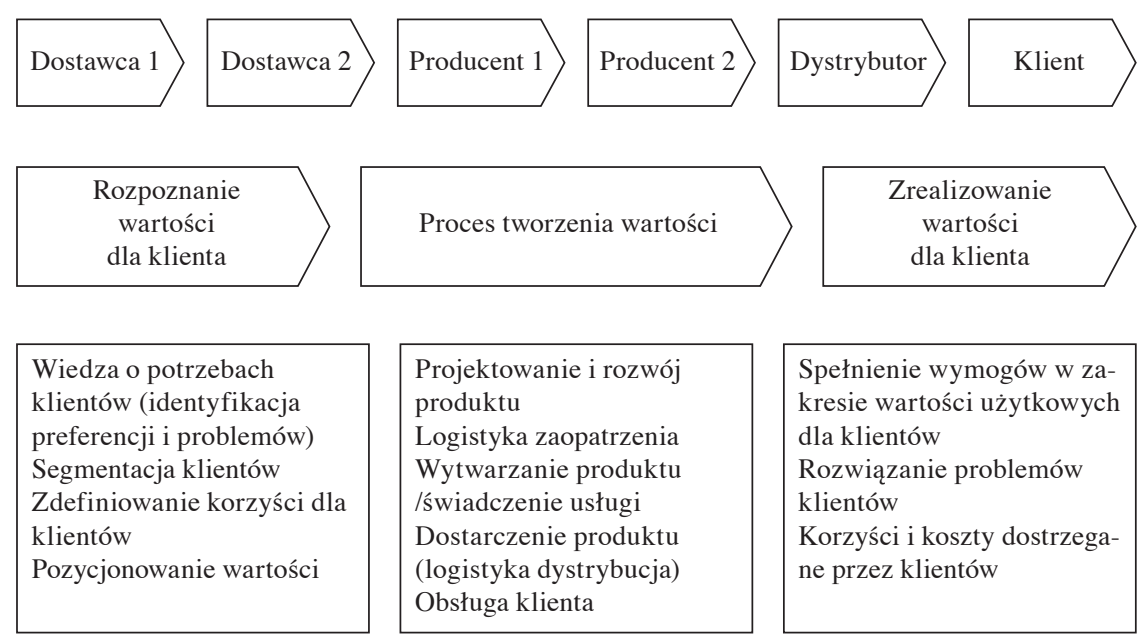

Rys. 2. Miejsce klienta w systemie tworzenia wartości Źródło: opracowanie własne.

\section{Etap 2. Analiza procesów tworzacych łańcuch wartości przedsiębiorstwa}

Ważnym etapem w analizie łańcucha wartości jest identyfikacja procesów realizowanych w przedsiębiorstwie oraz ich ocena z punktu widzenia skuteczności i efektywności realizacji. Jest to możliwe dzięki ustaleniu i opracowaniu określonych miar oraz sposobów pomiaru osiąganych efektów każdego procesu.

Problematyka procesów wyjaśniana jest na gruncie nie tylko nauki o zarządzaniu, ale także w naukach prawniczych, przyrodniczych, czy medycznych. W niniejszym artykule proces będzie rozpatrywany jako zbiór działań powiązanych relacjami czasowymi i przestrzennymi ukierunkowany na klientów, określony przez przepływy materiałów i informacji, przenikający granice poszczególnych sfer działalności przedsiębiorstwa, obejmujący pierwotne i wtórne aktywności tworzące wartość [Logistyka, 2011, s. 97]. Efektem końcowym procesu jest zatem wartość produktu lub usługi akceptowana przez klienta. Przyjęcie takiego podejścia w przedsiębiorstwie powoduje, że powinno ono starannie i systematycznie zarządzać wszystkimi procesami, które biorą udział w tworzeniu wartości dla 
klienta [Edwards, Braganza i Lambert 2000, s. 29]. Wyniki, jakie są osiągane w każdym procesie, można rozpatrywać w aspekcie skuteczności i efektywności takiego procesu [Skrzypek i Hofman 2010, s. 14].

Koncepcja przedsiębiorstwa zorganizowanego w sposób procesowy sięga lat 50. XX w. Procesowe podejście miało jednak wtedy inny wymiar. Wykorzystane było bowiem do strukturalizacji i formalizacji zarządzania produkcją. Obecnie zarządzanie procesowe ma zapewnić większą efektywność wszystkich działań, których rezultatem jest wzrost wartości dla klienta [Sopińska 2004, s. 52]. Dlatego zrozumienie roli i oczekiwań klienta stanowi bardzo ważny element we wdrożeniu zarówno podejścia procesowego, jak i działań zmierzających do poprawy efektywności funkcjonowania organizacji.

Procesowa analiza przedsiębiorstwa powinna zatem obejmować następujące etapy:

- określenie procesów realizowanych w przedsiębiorstwie,

- uświadomienie pracowników w zakresie roli procesów w tworzeniu wartości dodanej dla klienta,

- pomiar i ocena rezultatów procesów.

- propozycje doskonalenia procesów [Biazzo i Bernardi 2003, s. 154-156].

Syntetyczną prezentację etapów procesowej analizy przedsiębiorstwa zawiera tabela 1 .

Tabela 1. Etapy procesowej analizy przedsiębiorstwa

\begin{tabular}{|l|l|}
\hline \multicolumn{1}{|c|}{ Etap } & \multicolumn{1}{c|}{ Charakterystyka } \\
\hline $\begin{array}{c}\text { 1. Identyfikacja } \\
\text { i strukturyzacja } \\
\text { procesów realizo- } \\
\text { wanych w przed- } \\
\text { siębiorstwie }\end{array}$ & $\begin{array}{l}\text { W etapie tym należy zidentyfikować procesy główne oraz procesy czást- } \\
\text { kowe, powiązane ze sobą relacjami strukturalnymi następstwa lub rów- } \\
\text { noległości, relacjami czasowymi i logicznymi. Istotnym narzędziem uła- } \\
\text { twiającym precyzowanie tego typu szczegółów jest karta procesu. Oprócz } \\
\text { dokonania strukturalizacji procesu ważne jest stworzenie mapy (macie- } \\
\text { rzy) odpowiedzialności z uwzględnieniem komórek uczestniczących } \\
\text { w działaniach i ich roli. Ustalenie hierarchicznej struktury procesów jest } \\
\text { niezbędne dla przejrzystego przyporządkowania zakresu prac i odpowie- } \\
\text { dzialności za poszczególne procesy cząstkowe i działania. Na podstawie } \\
\text { struktury procesów możliwe jest określenie koncepcji systemu mierzenia } \\
\text { efektywności procesów. }\end{array}$ \\
\hline $\begin{array}{l}\text { 2. Ocena procesów } \\
\text { pod względem ich } \\
\text { udziału w procesie } \\
\text { tworzenia wartości } \\
\text { dodanej }\end{array}$ & $\begin{array}{l}\text { W kolejnym etapie analizy wyróżnione procesy (działania) realizowane } \\
\text { w przedsiębiorstwie powinny być ocenione pod względem ich udziału } \\
\text { generują procesy dla klienta, można je podzielić na: procesy podstawowe } \\
\text { (bezpośrednio wiążące się z tworzeniem wartości dla klienta, mają one } \\
\text { strategiczne znaczenie i zazwyczaj przebiegają przez wiele działów tra- } \\
\text { dycyjnej organizacji oraz „wiążą” dostawców z klientami, np. marketing } \\
\text { i obsługa klienta, projektowanie, wytwarzanie, dystrybucja, świadcze- } \\
\text { nie usług), procesy pomocnicze (wspierające działalność podstawową }\end{array}$ \\
\hline
\end{tabular}


cd. tabeli 1

\begin{tabular}{|c|c|}
\hline Etap & Charakterystyka \\
\hline & $\begin{array}{l}\text { i są dla jej skutecznej i prawidłowej realizacji uważane jako niezbędne, } \\
\text { np. wytwarzanie narzędzi, transport wewnętrzny, kontrola jakości, maga- } \\
\text { zynowanie, utrzymanie ruchu), procesy zarządcze (procesy informacyjno- } \\
\text {-decyzyjne uwzględniające aspekt dynamiczny oraz ich przebieg w okre- } \\
\text { ślonej strukturze organizacyjnej przedsiębiorstwa (aspekt statyczny). Do } \\
\text { procesów zarządzania zalicza się: zarządzanie strategią, zarząązanie } \\
\text { finansami, zarządzanie informacjami. } \\
\text { Ocena wartości procesów musi być przeprowadzona, biorąc zawsze pod } \\
\text { uwagę punkt widzenia klientów. }\end{array}$ \\
\hline $\begin{array}{l}\text { 3. Pomiar i ocena } \\
\text { efektywności } \\
\text { poszczególnych } \\
\text { procesów }\end{array}$ & $\begin{array}{l}\text { Wszystkie procesy realizowane w przedsiębiorstwie należy przejrzeć } \\
\text { pod względem ich ekonomicznej efektywności, czyli relacji osiąganych } \\
\text { efektów i ponoszonych nakładów. Jeżeli relacje nie mogą zostać wyrażane } \\
\text { w mierniku pieniężnym, to można wykorzystać mierniki niefinansowe } \\
\text { (np. czas produkcji lub obsługi klienta). Do oceny procesu można także } \\
\text { wykorzystać miary skuteczności, tj. stopień osiągnięcia założonego celu. } \\
\text { Procesy realizowane w przedsiębiorstwie można podzielić w zależno- } \\
\text { ści od wpływu na subiektywnie postrzeganą przez klienta wartość oraz } \\
\text { z uwagi na efektywność wykonywania. Najbardziej pożądanym stanem są } \\
\text { procesy (działania), które zwiększają wartość dla klienta i są wykonywane } \\
\text { efektywnie. Jedną z istotnych decyzji w obszarze zarządzania procesami } \\
\text { jest zatem wybór mierników oceny poszczególnych procesów. Pomiar } \\
\text { wyników procesów według ustalonego zestawu mierników może w pełny } \\
\text { i systematyczny sposób pomóc ocenić, czy przedsiębiorstwo osiąga przy- } \\
\text { jęte cele, czy efektywnie przekształca nakłady w efekty i ukształtować } \\
\text { aktywnie posiadany systemu procesów. }\end{array}$ \\
\hline $\begin{array}{l}\text { 4. Doskonalenie } \\
\text { i projektowanie } \\
\text { procesów }\end{array}$ & $\begin{array}{l}\text { Doskonalenie procesów w zmiennych warunkach funkcjonowania staje } \\
\text { się wyzwaniem dla całej organizacji. Potrzebę tę wywołuje nieustanna } \\
\text { konkurencja kosztowa, a także presja na podnoszenie szeroko rozumianej } \\
\text { jakości. Kierownictwo przedsiębiorstwa po uzgodnieniu z właścicielami } \\
\text { procesów (osobami odpowiedzialnymi), w wyniku oceny bieżącej sytu- } \\
\text { acji może podjąć decyzje o przeprowadzeniu doskonalenia procesów już } \\
\text { istniejących w celu poprawy efektywności całego łańcucha wartości lub } \\
\text { opracowania nowych procesów. Ten etap ma spowodować polepszenie } \\
\text { jakości i (lub) produktywności, obniżyć koszty działan, a w ostatecznej } \\
\text { ocenie przyczynić się do wzrostu efektywności całej organizacji. Można } \\
\text { wyróżnić dwa kryteria oceny doskonalenia procesów w organizacjach: } \\
\text { ciągłości procesu doskonalenia oraz poziomów doskonalenia procesów. }\end{array}$ \\
\hline
\end{tabular}

Źródło: opracowanie własne na podstawie: [Logistyka, 2011, s. 141; Skrzypek i Hofman 2010, s. 68-75; Horowski i Kononowicz 2002, s. 34-37; Hofman 2007, s. 225-267; Procesy i projekty logistyczne, 2008, s. 77, s. 79; Cyfert 2006, s. 37-38, s. 41; Błoński i Kondracki 2004, s. 64].

\section{Etap 3. Analiza kosztów w istniejacej konfiguracji łańcucha wartości}

Realizacja każdego procesu (działania) powoduje ponoszenie kosztów, ale tylko niektóre procesy kreują wartość dostarczaną klientowi. Procesy niewpływające 
na zwiększenie wartości dla klienta muszą być ograniczane i eliminowane, zaś procesy podnoszące wartość produktu lub usługi powinny być efektywnie rozwijane, mimo że będzie z tym związane ponoszenie dodatkowych kosztów. Analiza procesów pod kątem ich wpływu na kreowanie wartości dla klienta oraz efektywności ich wykonywania jest podstawową metodą umożliwiającą podejmowanie decyzji prowadzących do poprawy przyszłej efektywności działalności firmy.

Zarządzanie procesami w sferze operacyjnej powinno być zintegrowane z kontrolą strategiczną, ponieważ inne będą cele firmy realizującej strategię przywództwa kosztowego (standardowe produkty po możliwie najniższym koszcie), a inne firmy ukierunkowanej na wyróżnienie produktów (unikalne technologie i relacje z klientem, lojalność wobec marki). Strategie kosztowe będą również modyfikowane w zależności od stanu gospodarki kraju (kryzys czy prosperity), a także będą zależne od fazy cyklu życia firmy (start-up czy firma dojrzała).

Tradycyjne ujęcie zakłada, że poziom kosztów własnych ponoszonych przez przedsiębiorstwo zależy od rozmiarów jego działalności mierzonych wielkością produkcji, co wiąże się z koncepcją analizy „koszt-rozmiary działalności-zysk” (cost-volume-profit) oraz z podziałem kosztów na stale i zmienne. Przy czym w literaturze z zakresu rachunkowości zarządczej podejściu temu przypisuje się wymiar operacyjny i krótkoterminowy [Jaruga, Nowak i Szychta 2001, s. 386]. W ujęciu strategicznym konieczne jest skierowanie uwagi na inne niż rozmiary działalności czynniki wpływające na poziom kosztów w przedsiębiorstwie. Ich rozpoznanie stanowi ważne uzupełnienie analizy łańcucha wartości.

Rozpoznanie, pomiar i analiza czynników kosztotwórczych w przedsiębiorstwie to najważniejsze zadania rachunkowości w strategicznym zarządzaniu kosztami, mające znaczenie przede wszystkim w zdobywaniu przewagi konkurencyjnej.

Metodami pozwalającymi na zarządzanie kosztami w odniesieniu do łańcucha wartości są: rachunek kosztów docelowych (target costing), analiza i planowanie działań, rachunek kosztów działań (activity-based costing - ABC) [Stabryła 2012, s. 79-82], budżetowanie kosztów oparte na działaniach (activity-based budgeting - ABB), sterowanie rentownością produktów według grup klientów (obszarów sprzedaży), rekonstrukcje procesów gospodarczych (business proces reengineering - BPR), systemy „dokładnie na czas” (just-in-time - JIT), pomiar wyników i wyznaczanie wzorca (benchmarking), stałe usprawnianie (continuous improvement - CI) [Jaruga, Nowak i Szychta 2001, s. 839].

W większości łańcuchów wartości każde działanie ma odrębną strukturę kosztową, determinowaną przez różne nośniki kosztów (cost drivers). Analiza kosztów wymaga zatem rozbicia łańcucha wartości przedsiębiorstwa w celu zidentyfikowania:

- relatywnego znaczenia każdego działania w odniesieniu do całkowitego kosztu produktu, 
- nośników kosztów dla każdego działania i oceny względnej efektywności, $\mathrm{z}$ jaką przedsiębiorstwo wykonuje każdy proces,

- wpływu kosztów jednego procesu na koszty innego (powiązania między procesami),

- działań, jakie należy wykonać własnymi siłami i tych, które należy zlecić na zewnątrz (z tytułu możliwości redukcji kosztów) [Grant 2011, s. 303-304].

\section{Etap 4. Ocena zasobów i kompetencji w łańcuchu wartości przedsiębiorstwa}

Do ciągłego i dynamicznego dodawania wartości organizacji poprzez realizację w niej procesów potrzeba szczególnych kompetencji, które pozwolą „robić coś” lepiej niż konkurenci. Kompetencje określane są jako zdolności do wykonywania przez organizację „czegoś dobrze” w pewnym zakresie. Są one wypadkową uczenia się, doświadczenia, możliwości analityczno-syntetyzujących informacji, postawy wobec ryzyka itp. [Rokita 2005, s. 142] Nie są one wielkością stałą, ale wraz z upływem czasu szybko się zmieniają. Znajdują one zastosowanie w konkretnych działaniach określonego projektu (biznesu), np. w łańcuchu wartości dodanej. Do ciągłego i dynamicznego dodawana wartości przedsiębiorstwa potrzebne są szczególne umiejętności. Poziom tych umiejętności może spowodować, że wszystkie zasoby organizacji mają szanse zostać źródłem przewagi konkurencyjnej, gdy kapitał:

- rzeczowy umożliwia osiągnięcie przewagi technologicznej (koszty jego pozyskania i wykorzystania są znacznie niższe niż u konkurentów),

- finansowy jest pozyskiwany na korzystniejszych warunkach niż u konkurentów (umożliwia uzyskanie wysokiej stopy zwrotu i wysokiej płynności),

- ludzki ma wyższe kwalifikacje niż u konkurencji (efektywność jego wykorzystania jest wyższa niż u konkurentów),

- wiedzy daje większe bazy danych niż u konkurentów (przy wysokich możliwościach ich wykorzystania),

- reputacji umożliwia stosowanie wyższych cen niż u konkurentów (wpływa na pozycję firmy na giełdach, a marka jest czynnikiem zwiększającym poziom sprzedaży) [Łańcuch tworzenia wartości dodanej przedsiębiorstwa, 2007, s. 51-52].

W strategii tworzenia wartości niezbędne jest posiadanie kluczowych kompetencji [Bratnicki 2000, s. 17]. W dużym stopniu o strukturze działań rozstrzygają wypracowane kompetencje m.in.: ekonomiczne, menedżerskie, psychologiczne

${ }^{7}$ Są to wiązki zasobów, procesów i zdolności leżących u podłoża przewagi konkurencyjnej przedsiębiorstwa, dające dostęp do ważnych rynków, czyniące znaczny wkład w dostrzegane przez klientów korzyści, umożliwiające obniżkę kosztów, utrudniające naśladowanie przez konkurencję czy też pozwalające stworzyć strategiczną architekturę sieci więzi zewnętrznych i wewnętrznych stanowiących podłoże tworzenia wartości dodanej i zarządzać nią [Thompson i Richardson 1996, s. 5-19]. 
[Strategor 2001, s. 63]. Posiadanie określonych kompetencji pozwala przedsiębiorstwu na wybór określonego modelu biznesu, co nie oznacza, że przedsiębiorstwo poprzez nawiązywanie relacji z aliantami nie może wzbogacić już posiadanych (wypracowanych) kompetencji i dokonać rekonfiguracji zbudowanego wcześniej łańcucha wartości ${ }^{8}$.

Ze względu na zakres posiadanych (i dostęp do) kompetencji oraz rolę pełnioną w łańcuchu tworzenia wartości przedsiębiorstwo może wybrać następujące modele biznesu:

- model dyrygenta, w którym firma zamiast integrować, koordynować i kontrolować wszystkie aktywności potrzebne w sektorze, decyduje się na outsourcing tych aktywności, które nie są kluczowe oraz stworzenie sieci partnerów, pełniąc w niej rolę koordynatora,

- model operatora, w którym firma koncentruje się na jednym wybranym aspekcie łańcucha wartości,

- model integratora, w którym firma rozbudowuje swój łańcuch wartości o kolejne ogniwa w celu uzyskania kontroli nad całym procesem wytwarzania i zawłaszczania wartości [Obłój 2002, s. 135].

Kiedy źródłem zysku i podstawą innowacyjnego modelu działalności jest specyficzna konfiguracja procesów realizowanych przez przedsiębiorstwo to organizacja analizuje wartość poszczególnych składowych łańcucha wartości, zwracając szczególną uwagę na konkretny element bądź rozbudowuje badany łańcuch wartości. $\mathrm{Z}$ tego względu może ona wybrać następujące modele biznesu: model zysku wieloelementowy, model zysku z łącznicy, model zysku ze specjalizacji w konkretnej dziedzinie działania, model zysku posprzedażny oraz model zysku z pozycji w łańcuchu wartości [Slywotzky, Morrison i Andelman 2000, s. 81].

Tworzenie i rozwój kluczowych kompetencji jako źródła przewagi konkurencyjnej wymaga także przeprojektowania istniejących struktur organizacyjnych. Analiza zasobów i kompetencji przedsiębiorstwa powinna być także uzupełniona o analizę zasobów i kompetencji konkurentów, partnerów w sieci łańcucha wartości, gdyż w ten sposób będzie można uzyskać informacje i ocenić możliwości wytworzenia i dostarczenia wartości dodanej klientom [Szymura-Tyc 2006, s. 115].

Etap 5. Ocena relacji utrzymywanych wewnątrz i na zewnatrz łańcucha wartość przedsiębiorstwa

P. Drucker pisał, że jedną z największych zmian, z którą muszą się zmierzyć współcześni menedżerowie, jest ciągle przyspieszający wzrost relacji bizneso-

\footnotetext{
${ }^{8}$ Model biznesowy to „połączenie koncepcji strategicznej firmy i technologii jej praktycznej realizacji rozumianej jako budowa łańcucha wartości pozwalającego na skuteczną eksploatację oraz odnowę zasobów i umiejętności” [Obłój 2002, s. 97-98].
} 
wych opartych na partnerstwie, a nie bezpośrednim stosunku władzy i własności. W tworzeniu wartości, w stopniu wyższym niż kiedykolwiek wcześniej, organizacje opierają się na różnego rodzaju dobrowolnych przedsięwzięciach współpracy [Latusek-Jurczak 2011, s. 11].

Współczesne otoczenie wymusza na licznych przedsiębiorstwach tworzenie różnego rodzaju relacji (powiązań), gdyż organizacje coraz rzadziej są w stanie samodzielnie uczestniczyć w walce o przewagę konkurencyjną. W zależności od konkretnych uwarunkowań danej organizacji i jej otoczenia, cele tworzenia układów kooperacyjnych mogą być różne ${ }^{9}$. Zasadniczą determinantą tworzenia układów kooperacyjnych jest zdobycie dostępu do wiedzy i internalizacja, obniżenie kosztów, wzmocnienie pozycji rynkowej [Grant i Baden-Fuller 2004, s. 61-84]. Obecnie relacje międzyorganizacyjne stają się coraz ważniejsze, gdyż umożliwiają przedsiębiorstwom dostęp do nowych informacji, zasobów, rynków i technologii. Sieci zewnętrzne są wartościowe i cenne z uwagi na stwarzanie przedsiębiorstwom w nich uczestniczących możliwości zdobywania nowych zdolności oraz uczenia się nowych umiejętności [Macias 2009, s. 28].

W budowaniu łańcucha wartości uczestniczyć może wiele podmiotów, dlatego też ich liczba, sposób i zakres powiązań może w sposób istotny wpływać na uzyskiwaną wartość dodaną oraz możliwości osiągania przewagi konkurencyjnej na rynku.

Relacje w łańcuchu wartości dotyczą łańcucha zewnętrznego: dostawców, producentów, dystrybutorów i klientów, ale można je rozpatrywać także pod względem relacji wewnętrznych w granicach jednego przedsiębiorstwa ${ }^{10}$. Powią-

${ }^{9}$ Kooperacja przedsiębiorstw może obejmować różne dziedziny, zależnie od tego, jaki jest łańcuch tworzenia wartości i jakie role odgrywają w nim poszczególni partnerzy [Walas-Trębacz 2004].

${ }^{10}$ Ważnym zagadnieniem w tworzeniu efektywnego łańcucha wartości jest określanie granic przedsiębiorstwa. Granice stanowią istotną składową przedsiębiorstwa i determinują one możliwość prawidłowego definiowania aktywności organizacji i zachowań jej uczestników. Granice organizacji wyznaczają zakres oddziaływania organizacji i stanowią mechanizm integracji organizacji z otoczeniem, pozwalający na realizację działań nakierowanych na zapewnienie jej przetrwania i rozwoju. Natomiast granice w organizacji mogą być postrzegane w kategoriach mechanizmów rozgraniczania wewnętrznych obszarów aktywności oraz mechanizmów integracji elementów składowych organizacji. Dążąc do zapewnienia równowagi z otoczeniem, organizacje mogą wykorzystywać trzy typy mechanizmów zarządzania granicami: rozszerzanie, skracanie bądź buforowanie [Cyfert 2012a, s. 17]. Tak więc wraz ze zmianami struktury łańcucha wartości ulegają zmianie granice organizacji i granice w organizacji. Analizując łańcuch wartości, należy zatem uwzględniać stosowane w organizacji rodzaje mechanizmów zarządzania jego granicami. Jedną z ważnych ról kierowniczych w zarządzaniu granicami jest rola zarządzania tożsamością organizacji, która wpływa m.in. na definiowanie pozycji w łańcuchu tworzenia wartości w branży [Cyfert 2012b, s. 189]. Określenie granic łańcucha wartości przedsiębiorstwa jest także ważne z tytułu transakcji zarówno tych, które odbywają się na rynku (między danym przedsiębiorstwem a jego kontrahentami), a tymi które są zlokalizowane wewnątrz firmy [Gorynia 1998, s. 443]. 
zanie występuje wówczas, gdy istnieje określony stopień współzależności między działaniami. Oznacza to, że poszczególne działania występujące w łańcuchu wartości najczęściej nie są wzajemnie od siebie odizolowane i wywierają wpływ na przychody i koszty innych działań.

Wszystkie relacje (powiązania), niezależnie od rodzaju, są istotne ze względu na potencjalne możliwości sterowania ich wpływem na efektywność działania przedsiębiorstwa. Znaczenie powiązań pionowych zachodzących między danym przedsiębiorstwem a jego dostawcami i odbiorcami polega na tym, że są one często wykorzystywane w celu uzyskania korzyści finansowych przez wszystkie powiązane strony. Należy szukać więc takich usprawnień w zakresie tych relacji (powiazań), które pozwalają poprawić sytuację kosztową zarówno przedsiębiorstwa, jak i kontrahentów [Strategiczne zarzadzanie kosztami, 2006, s. 119-120].

Obecny rozwój wielokierunkowych porozumień coraz częściej zastępuje proste relacje bezpośredniej rywalizacji. Strategie rozwoju dostosowane do tych wyzwań są ukierunkowane na tworzenie tzw. ekosystemów biznesu, czyli wielostronnych sieci powiązań z dostawcami, klientami, konkurentami [Kaleta 2000, s. 150-151]. W wyniku coraz ściślejszych powiązań partnerskich firm z klientami, $\mathrm{z}$ dostawcami, granice zewnętrzne tych firm stają się bardziej płynne, co wiąże się $\mathrm{z}$ upowszechnieniem i rozwojem sieci informatycznych i powoduje powstawanie firm sieciowych czy wirtualnych [Brilman 2002, s. 425]. Praktyka przedsiębiorstw wskazuje, że współpraca jest często lepszym niż konkurencja rozwiązaniem dla obniżki kosztów transakcyjnych, pozyskania nowych technologii, przyspieszenia innowacji, pozyskania wiedzy i pokonania barier na rynku krajowym i zagranicznym [Dunning 1995, s. 467].

Konstrukcja łańcuchów wymusza współpracę z usługodawcami, konkurentami, instytucjami finansowymi, ale także i uczelniami wyższymi, administracją publiczną. Tylko takie kooperacyjne działania pozwalają na osiągnięcie różnych celów: ekonomicznych, technicznych, społecznych i ekologicznych. Obecnie można zauważyć, że zarówno strategie, jak i powiązania mają charakter hybrydowy, rzadko bowiem można wyróżnić w działalności przedsiębiorstw łańcuch wartości tzw. czysty. W rezultacie przedsiębiorstwa, które mają swoje partykularne interesy, coraz częściej uczestniczą jednocześnie w kilku łańcuchach wartości [Świerczek 2007, s. 74-77]. Zatem istotnymi obszarami, które muszą być

Przedsiębiorstwo może także prowadzić działalność w różnych sektorach, dlatego też ważne jest określenie granic dla każdego łańcucha wartości z osobna, gdyż może ono zajmować różne pozycje w każdym sektorze, wykorzystywać różne zasoby i kompetencje, wybierać odmienne strategie konkurowania, kierować ofertę do różnych segmentów rynku oraz uzyskiwać zróżnicowane poziomy wartości dodanej z każdego sektora itd. Wprowadzając zmiany w procesach organizacjii ulegają zmianie także granice jego łańcucha wartości. Diagnozowanie i zarządzanie granicami łańcucha wartości jest tym trudniejsze, im bardziej przedsiębiorstwo wchodzi w różnego typu relacje z innymi podmiotami oraz uczestniczy w różnie skonfigurowanych sieciach. 
poddane analizie w zakresie możliwości minimalizacji ryzyka i kontroli kosztów w łańcuchu wartości są: zarządzanie relacjami z dostawcami, integracja łańcucha wartości [Jesionek 2007, s. 1] oraz granice określające poziom aktywności w łańcuchu wartości przedsiębiorstwa.

Należy także pamiętać o tym, że na charakter i efektywność tworzonych relacji w łańcuchu wartości ma wpływ wiele czynników, m.in.: rodzaj sektora, zakres i skala działalności, złożoność produktu, liczba uczestników w łańcuchu wartości, cele i oczekiwania partnerów, możliwości wyboru partnerów, poziom zaufania między partnerami, sposoby współpracy oraz sposoby konkurowania między partnerami, mechanizmy koordynacji w łańcuchu, stopień integracji łańcucha, przyjęty model biznesu, dostęp do informacji i wiedzy, stopień internacjonalizacji przedsiębiorstw, różnice kulturowe, doświadczenie partnerów w zakresie istniejących relacji, poziom i zakres kluczowych kompetencji, miejsce i pozycja partnerów w łańcuchu wartości, poziom ryzyka w tworzeniu relacji, zakres i częstotliwość zmian w technologii, postępujący proces globalizacji itp.

\section{Zakończenie}

Obecnie o uzyskaniu przewagi konkurencyjnej przedsiębiorstwa na rynku coraz częściej decydują: wybór modelu biznesu na podstawie łańcucha wartości, określenie skutecznej strategii konkurowania na rynku, efektywne wykorzystanie zasobów i umiejętności a także zakres wykorzystywanych technologii informatycznych, które umożliwiają zmiany procesów biznesu.

Zaprezentowana metodyka analizy łańcucha wartości przedsiębiorstwa powinna stanowić jedno z ważnych narzędzi diagnostycznych i koncepcyjnych dla menedżerów w wyborze strategii konkurowania, gdyż cechuje ją orientacja na podstawowe atrybuty współczesnego przedsiębiorstwa, tzn. na procesy, klienta oraz efektywność. W zależności od wybranego kierunku doskonalenia łańcucha wartości należy dobierać określony zestaw metod wspomagających realizację obranego celu [Walas-Trębacz 2012, s. 215].

Zastosowanie metodyki analizy łańcucha wartości przedsiębiorstwa nabiera szczególnego znaczenia wobec zanikania granic przedsiębiorstw i powstawania tzw. rozszerzonych przedsiębiorstw. Szczególny wpływ na kształtowanie łańcucha wartości przedsiębiorstwa wywiera proces globalizacji, struktura sektora oraz zakres i możliwości kompetencyjne przedsiębiorstwa. Zatem analiza przebiegu procesów, sieci powiązań, a także identyfikacja krytycznych ogniw (procesów) powinna prowadzić do wyboru najkorzystniejszej struktury łańcucha wartości, a w konsekwencji do wyboru efektywnej strategii wzrostu wartości przedsiębiorstwa. 


\section{Literatura}

Beliczyński J. [2011], Analiza systemu zarządzania wartościa dla klienta [w:] Przegląd problemów doskonalenia systemów zarządzania przedsiębiorstwem, red. A. Stabryła, Wydawnictwo MFiles.pl, Kraków.

Biazzo S., Bernardi G. [2003], Process Management Practices and Quality System Standards. Risks and Opportunities of New ISO 9001 Certification, „Business Process Management Journal", nr 2.

Błoński M., Kondracki K. [2004], Zarzqdzanie na przełomie wieków, Wydawnictwo Hays Personel, Warszawa.

Bratnicki M. [2000], Kompetencje przedsiębiorstwa. Od określenia kompetencji do zbudowania strategii, Agencja Wydawnicza Placet, Warszawa.

Brilman J. [2002], Nowoczesne koncepcje i metody zarzadzania, PWE, Warszawa.

Christopher M. [2000], Logistyka i zarzadzanie łańcuchem dostaw, Strategie obniżki kosztów i poprawy poziomu usług, Polskie Centrum Doradztwa Logistycznego, Warszawa.

Czakon W. [2003], Operacyjne rozwinięcia koncepcji łańcucha wartości, „Przegląd Organizacji”, nr 9.

Cyfert S. [2006], Strategiczne doskonalenie architektury procesów w zarządzaniu przedsiębiorstwem, Wydawnictwo Akademii Ekonomicznej w Poznaniu, Poznań.

Cyfert S. [2012a], Mechanizmy zarzadzania granicami - propozycja teoretycznego ujęcia $i$ wyniki badań empirycznych, „Współczesne Zarządzanie”, nr 3.

Cyfert S. [2012b], Role organizacyjne w zarzadzaniu granicami-propozycja definiowania $i$ wyniki badań empirycznych [w:] Metody badania i modele rozwoju organizacji, red. A. Stabryła, S. Wawak, MFiles.pl, Kraków.

Dunning J.H. [1995], Reappraising of the Eclectic Paradigm in the Age of Alliance Capitalism, ,Journal of International Business Studies, vol. 26, nr 3.

Edward C., Braganza A., Lambert R. [2000], Understanding and Managing Process Initiatives: A Framework for Developing Consensus, ,Knowledge and Process Management", vol. 7, nr 1.

Gorynia M. [1998], Pośrednictwo w handlu zagranicznym a teoria kosztów transakcyjnych, ,Ekonomista”, nr 4.

Grant R.M., Baden-Fuller Ch. [2004], A Knowledge Accessing Theory of Strategic Alliances, ,Journal of Management Studies”, vol. 41.

Grant R.M. [2011], Współczesna analiza strategii, Oficyna a Wolters Kluwer business, Warszawa

Hofman M. [2007], Controlling procesów w polskich przedsiębiorstwach, Annales UMCS, Sectio H Oeconomia, Wydawnictwo Uniwersytetu Marii Curie-Skłodowskiej, Lublin.

Horowski W., Kononowicz Ł. [2002], Strategia podnoszenia wartości przedsiębiorstwa w zarządzaniu procesami, „Controlling i Rachunkowość Zarządcza”, nr 5.

Jaruga A.A., Nowak W.A., Szychta A. [2011], Rachunkowość zarzadcza. Koncepcje $i$ zastosowania, Wyższa Szkoła Przedsiębiorczości i Zarządzania, Łódź.

Jesionek R. [2007], Globalne łańcuchy wartości, „CIO - Magazyn Dyrektorów IT”, nr 3. Kafel T. [2002], Metodyczne aspekty diagnozy strategicznej przedsiębiorstwa, Zeszyty Naukowe Akademii Ekonomicznej w Krakowie, nr 593, Kraków. 
Kaleta A. [2000], Strategia konkurencji w przemyśle, Wydawnictwo Akademii Ekonomicznej we Wrocławiu, Wrocław.

Kaplan R.S., Norton D.P. [2002], Strategiczna karta wyników. Jak przełożyć strategie na działanie, Wydawnictwo Naukowe PWN, Warszawa.

Kotler Ph. [2005], Marketing, Dom Wydawniczy Rebis, Poznań.

Koźmiński A.K. [2004], Zarzązanie w warunkach niepewności, Wydawnictwo Naukowe PWN, Warszawa.

Latusek-Jurczak D. [2011], Zarzadzanie międzyorganizacyjne, Oficyna a Wolters Kluwer business, Warszawa.

Logistyka, Teoria i praktyka [2011], red. S. Krawczyk, Difin, Warszawa.

Łańcuch tworzenia wartości dodanej przedsiębiorstwa [2007], red. B. Woźniak-Sobczak, Prace Naukowe Akademii Ekonomicznej w Katowicach, Katowice.

Macias J. [2009], Relacje międzyorganizacyjne jako nowy zasób strategiczny przedsiębiorstwa, „Przegląd Organizacji”, nr 12.

Matwiejczuk R. [2010], Przesłanki tworzenia wartości w łańcuchu wartości, Przegląd Organizacji”, nr 5.

Obłój K. [2002], Tworzywo skutecznych strategii, PWE, Warszawa.

Peck H. [2005], Drivers of Supply Chain Vulnerability: An Integrated Framework, „International Journal of Physical Distribution \& Logistics Management”, vol. 35, nr 4.

Porter M.E. [1985], Competitive Advantage. Creating and Sustaining Superior Performance, The Free Press, New York.

Procesy i projekty logistyczne [2008], red. S. Nowosielski, Uniwersytet Ekonomiczny we Wrocławiu, Wrocław.

Rokita J. [2005], Zarzadzanie strategiczne, tworzenie przewagi konkurencyjnej, PWE, Warszawa.

Rutkowski K. [2000], Zintegrowany łańcuch dostaw. Doświadczenia globalne i polskie, Szkoła Główna Handlowa, Warszawa.

Skrzypek E., Hofman M. [2010], Zarzadzanie procesami w przedsiębiorstwie, Identyfikowanie, pomiar, usprawnianie, Oficyna a Wolters Kluwer business, Warszawa.

Slywotzky A., Morrison D.J., Andelman B. [2000], Strefa zysku. Strategiczne modele działalności, PWE, Warszawa.

Sopińska A. [2004], Procesowa organizacja przedsiębiorstwa [w:] Procesowe podejście w zarzadzaniu TQM, red. M. Romanowska, M. Trocki, Szkoła Główna Handlowa, Warszawa.

Stabryła A. [2007], Zarzadzanie strategiczne w teorii i praktyce firmy, Wydawnictwo Naukowe PWN, Warszawa-Kraków.

Stabryła A. [2012], Zarzadzanie procesowe [w:] Podstawy organizacji i zarzadzania. Podejścia i koncepcje badawcze, red. A. Stabryła, Uniwersytet Ekonomiczny w Krakowie, Kraków.

Strategiczne zarzadzanie kosztami [2006], red. E. Nowak, Oficyna Ekonomiczna, Kraków.

Strategor [2001], Zarzadzanie firma, PWE, Warszawa.

Szymura-Tyc M. [2004], Wartość dla klienta w teorii wyboru, zachowań konsumentów i marketingu [w:] Wartość w naukach ekonomicznych, red. H. Zadora, Wydawnictwo Politechniki Śląskiej, Gliwice. 
Szymura-Tyc M. [2006], Marketing we współczesnych procesach tworzenia wartości dla klienta i przedsiębiorstwa, Prace Naukowe Akademii Ekonomicznej w Katowicach, Katowice.

Świerczek A. [2007], Od łańcuchów dostaw do sieci dostaw, „Logistyka”, nr 1.

Thompson J.L., Richardson B. [1996], Strategic and Competitive-Success: Towards a Model of the Comprehensively Competent Organization, „Management Decision”, nr 2.

Walas-Trębacz J. [2004], Kooperacja zewnętrzna $w$ zarządzaniu przedsiębiorstwem, Zeszyty Naukowe Małopolskiej Wyższej Szkoły Ekonomicznej, nr 5, Tarnów.

Walas-Trębacz J. [2012], Znaczenie analizy łańcucha wartości dla organizacji [w:] Metody badania i modele organizacji, red. A. Stabryła, S. Wawak, Wydawnictwo Mfiles.pl, Kraków.

Webb J., Glie Ch. [2001], Reversing the Value Chain, „Journal of Business Strategy”, nr 3-4.

\section{A Methodology for Analysing the Enterprise Value Chain}

The purpose of this paper is to present one of the ways to increase the value of a business by identifying and assessing the structure of its value chain. The article indicates conditions contributing to the need to increase research on the enterprise value chain.

The main part of the article presents a methodology for analysing the value chain through the characteristics of its various stages. These include identifying the needs and expectations of clients, analysing the processes that make up an enterprise's value chain, analysing the costs of processes in the existing configuration of the value chain, evaluating resources and competences in the value chain and studying the relationships between companies in the value chain.

An important aspect in the analysis of the value chain is to establish a set of criteria that will make it possible to assess three areas: how the existing model of the value chain in the enterprise functions from the point of view of satisfying customer needs, the value creation process as a cost, and the effectiveness of all taken action.

Keywords: value chain, value chain model, value chain analysis methodology, enterprise process analysis. 